University of Nebraska - Lincoln

DigitalCommons@University of Nebraska - Lincoln

Papers in Veterinary and Biomedical Science

Veterinary and Biomedical Sciences,

Department of

2018

Tellurite Resistance in Shiga Toxin-Producing Escherichia coli

Gentry L. Lewis

Quentin R. Jorgensen

John Dustin Loy

Rodney A. Moxley

Follow this and additional works at: https://digitalcommons.unl.edu/vetscipapers

Part of the Biochemistry, Biophysics, and Structural Biology Commons, Cell and Developmental Biology Commons, Immunology and Infectious Disease Commons, Medical Sciences Commons, Veterinary Microbiology and Immunobiology Commons, and the Veterinary Pathology and Pathobiology Commons

This Article is brought to you for free and open access by the Veterinary and Biomedical Sciences, Department of at DigitalCommons@University of Nebraska - Lincoln. It has been accepted for inclusion in Papers in Veterinary and Biomedical Science by an authorized administrator of DigitalCommons@University of Nebraska - Lincoln. 


\title{
Tellurite Resistance in Shiga Toxin-Producing Escherichia coli
}

\author{
Gentry L. Lewis, Quentin R. Jorgensen, \\ John D. Loy, \& Rodney A. Moxley \\ School of Veterinary Medicine and Biomedical Sciences, University of Nebraska-Lincoln, \\ 1880 N. 42nd St., Lincoln, NE 68583-0905, USA \\ Correspondence: Rodney A. Moxley rmoxley1@unl.edu
}

\begin{abstract}
Potassium tellurite $\left(\mathrm{K}_{2} \mathrm{TeO}_{3}\right)$ is an effective selective agent for O157: $\mathrm{H} 7$ Shiga toxinproducing Escherichia coli (STEC), whereas tellurite resistance in non-O157 STEC is variable with information on $\mathrm{O}_{45}$ minimal. High-level $\mathrm{K}_{2} \mathrm{TeO}_{3}$ resistance in STEC is attributable to the ter gene cluster with terD an indicator of the cluster's presence. Polymerase chain reactions for ter $D$ and $\mathrm{K}_{2} \mathrm{TeO}_{3}$ minimum inhibitory concentration (MIC) determinations in broth cultures were conducted on 7O STEC and 40 non-STEC control organisms. Sixty-six STEC strains (94.3\%) were terD+ compared to 28 control organisms $(70.0 \% ; P<0.001)$. The prevalence of terD in 0103 STEC strains was $70 \%$, whereas in all other serogroups it was $\geq 90 \%$. The $\mathrm{K}_{2} \mathrm{TeO}_{3}$ geometric mean MIC ranking for STEC serogroups from highest to lowest was O111 > O26 $>0145>0157>0103>0121=\mathrm{O}_{4}$. The $\mathrm{K}_{2} \mathrm{TeO}_{3}$ geometric mean MIC was significantly higher in terD + than in terD-STEC, but not in terD+ versus terD-control strains. Resistance to $\mathrm{K}_{2} \mathrm{TeO}_{3}$ ( $\mathrm{MIC} \geq 25 \mathrm{mg} / \mathrm{L}$ ) was exhibited by $65 / 66 \mathrm{terD}+$ and o/4 terD-STEC strains, compared to $12 / 28$ terD+ and 8/12 terD-control strains. These results confirm previous studies showing the significantly higher prevalence of the ter gene cluster in STEC strains, and the relationship between these genes

Published in Current Microbiology 75 (2018), pp 752-759.

DOI: https://doi.org/10.1007/s00284-018-1444-X

Copyright (C) 2018 Springer Science+Business Media, LLC, part of Springer Nature. Used by permission.

Submitted 20 October 2017; accepted 27 January 2018; published 8 February 2018.
\end{abstract}


and $\mathrm{K}_{2} \mathrm{TeO}_{3}$ resistance in STEC and especially intimin (eae)-positive STEC, in contrast to non-STEC organisms. $\mathrm{O} 45$ and 0121 STEC, although frequently terD positive, on average had significantly lower levels of $\mathrm{K}_{2} \mathrm{TeO}_{3}$ resistance than $\mathrm{O} 26$, O111, and O145 STEC.

\section{Introduction}

Strains of Shiga toxin-producing Escherichia coli (STEC) were estimated to have caused approximately $16 \%$ of all hospitalized cases of foodborne illness in the United States from 2009 to 2010 [18]. Ruminants serve as a major reservoir of STEC, and are the primary source of contamination of human food and water [8]. A subset of STEC classified as enterohemorrhagic E. coli (EHEC) causes hemorrhagic colitis and hemolytic uremic syndrome [8]. In recent years, over 90\% of EHEC infections in the United States were due to seven serogroups, and the majority of the associated outbreaks were attributable to beef $[7,14]$. The U.S. Department of Agriculture Food Safety and Inspection Service (FSIS) has declared these seven EHEC serogroups (O26, O45, O103, O111, O121, O145, and O157) to be adulterants in raw, nonintact beef [19].

Culture-based detection methods for non-O157 STEC, including those for the detection of FSIS adulterants, are relatively insensitive and in need of improvement. Several factors contribute to this insensitivity, but major ones are the diversity of the microorganisms targeted and the high levels of background microbiota in specimens [20]. While enrichment increases viable target cells in a sample, selective agents must inhibit the growth of background flora. In 1993, Zadik et al. [22] reported that $\mathrm{K}_{2} \mathrm{TeO}_{3}$ incorporation into agar media improved the selection of 0157:H7 STEC. In 2000, Tarr et al. [15] reported the presence of a tellurite resistance and adherence-conferring island (TAI) on the chromosome of 0157:H7 STEC. The TAI included four open reading frames that were homologous to tellurite-resistance (ter) genes carried on plasmids in Alcaligenes sp. (pMER610) and Serratia marcescens (pR478) [11, 15, 16, 21]. Bielaszewska et al. [3] and Orth et al. [13] reported that the ter gene cluster containing ter $A-F$ and $-Z$ was correlated with growth of O26, and other non-O157 STEC, respectively, on $\mathrm{K}_{2} \mathrm{TeO}_{3}$ - containing media. Essential to a functional ter operon, terD is a practical marker of its presence $[10,13,17]$. However, Kerangart et al. [12] recently reported that although the ter operon is 
usually predictive of $\mathrm{K}_{2} \mathrm{TeO}_{3}$ resistance in non-O157 STEC this is not always the case, and more research on the STEC tellurite resistome will be required for the development of improved media for the recovery of STEC.

The objectives of this study were to determine the (1) prevalence of terD in a representative set of STEC strains and non-STEC control organisms; (2) minimum inhibitory concentration (MIC) of $\mathrm{K}_{2} \mathrm{TeO}_{3}$ for the same representative set of organisms; and (3) relationship between the prevalence of terD and the $\mathrm{K}_{2} \mathrm{TeO}_{3} \mathrm{MIC}$.

\section{Materials and Methods}

\section{Bacterial Strains}

One hundred ten bacterial strains, 70 STEC and 40 non- STEC controls, selected without knowledge of terD presence or absence, were included in this study. The STEC strains included ten of each USDAFSIS adulterant serogroup (Table 1). The STEC strains were obtained from the American Type Culture Collection, Michigan State STEC Repository, collaborating investigators (D. H. Francis, J. B. Luchansky, T. G. Nagaraja, A. D. O'Brien, and D. G. Renter), and field isolates from other studies (Moxley). Thirty-eight, 30, one, and one of the STEC strains were of human, cattle, unknown, and food (hamburger) origin, respectively (Table 1). STEC strains were characterized for O-antigen and virulence genes by an 11-plex PCR [2], and represented a mixture of virulence genotypes with all positive for $s t x_{1}, s t x_{2}$ or both, and 68 positive for eae. Control strains were obtained from the University of Nebraska-Lincoln Veterinary Diagnostic Center (Table 2). These strains included both Gram-positive and Gram-negative bacteria, with most representing enteric microbiota, and especially members of the Enterobacteriaceae family. Records of the host species origins of the individual control strains were not available.

\section{Polymerase Chain Reaction (PCR)}

Bacterial strains stored at $-80^{\circ} \mathrm{C}$ were streaked for isolation onto $5 \%$ sheep blood agar plates (Remel, Lenexa, Kansas; BAP) and incubated at $37^{\circ} \mathrm{C}$ for $24 \mathrm{~h}$. A DNA template was prepared for each strain 
Table 1 Minimum inhibitory concentrations (MIC) for $\mathrm{Ko}_{2} \mathrm{TeO}_{3}$ and polymerase chain reaction assay results for terD in representative STEC strains

\begin{tabular}{|c|c|c|c|c|c|c|c|c|}
\hline Strain & Origin $^{a}$ & Serotype $^{\mathrm{b}}$ & $s t x_{1}{ }^{b}$ & $s t x_{2}{ }^{b}$ & $e a e^{\mathrm{b}}$ & $\operatorname{ter} D^{\mathrm{b}}$ & $\mathrm{MIC}^{\mathrm{c}}$ & Resistance $^{\mathrm{d}}$ \\
\hline DEC10B & $\mathrm{H}$ & O26:H11 & + & - & + & + & 282.84 & + \\
\hline $97-3250$ & $\mathrm{H}$ & $\mathrm{O} 26: \mathrm{H} 11$ & + & + & + & + & 141.42 & + \\
\hline DA-10 & $\mathrm{H}$ & $\mathrm{O} 26: \mathrm{NM}$ & + & - & + & + & 141.42 & + \\
\hline 16272 & $\mathrm{C}$ & $\mathrm{O} 26$ & + & - & + & + & 282.84 & + \\
\hline $1577-88$ & $\mathrm{C}$ & $\mathrm{O} 26: \mathrm{H} 11$ & + & - & + & + & 100.00 & + \\
\hline Н3о & $\mathrm{H}$ & $\mathrm{O} 26: \mathrm{H} 11$ & + & - & + & + & 200.00 & + \\
\hline 2003-3014 & $\mathrm{H}$ & O26:H11 & + & + & + & + & 141.42 & + \\
\hline DEC10e & $\mathrm{C}$ & $\mathrm{O} 26: \mathrm{H} 11$ & + & - & + & + & 200.00 & + \\
\hline $413 / 89-1$ & $\mathrm{C}$ & $\mathrm{O} 26: \mathrm{H} 11$ & + & - & + & + & 200.00 & + \\
\hline IHIT2087 & $\mathrm{C}$ & $\mathrm{O} 26: \mathrm{H} 11$ & + & - & + & + & 141.42 & + \\
\hline DA-21 & $\mathrm{H}$ & $\mathrm{O} 45: \mathrm{H} 2$ & + & - & + & + & 50.00 & + \\
\hline DEC11C & $\mathrm{H}$ & $\mathrm{O} 45: \mathrm{H} 2$ & + & - & + & + & $35 \cdot 35$ & + \\
\hline MIo1-88 & $\mathrm{H}$ & $\mathrm{O} 45: \mathrm{H} 2$ & + & - & + & + & 50.00 & + \\
\hline $\mathrm{B} 8026-\mathrm{C} 1$ & $\mathrm{C}$ & $\mathrm{O} 45: \mathrm{H} 2$ & + & - & + & + & 12.50 & - \\
\hline B8227-C8 & $\mathrm{C}$ & $\mathrm{O} 45: \mathrm{H} 2$ & + & - & + & + & 282.84 & + \\
\hline CDC 96-3285 & $\mathrm{H}$ & $\mathrm{O} 45: \mathrm{H} 2$ & + & - & + & + & 141.42 & + \\
\hline 2000-3039 & $\mathrm{H}$ & $\mathrm{O} 45: \mathrm{H} 2$ & + & - & + & + & 25.00 & + \\
\hline 1.2622 & $\mathrm{C}$ & $\mathrm{O} 45: \mathrm{H} 12$ & + & - & - & - & 4.42 & - \\
\hline D88-28058 & $\mathrm{C}$ & $\mathrm{O} 45: \mathrm{NM}$ & + & - & + & + & 100.00 & + \\
\hline B8228-C2 & $\mathrm{C}$ & $\mathrm{O} 45: \mathrm{H} 2$ & + & - & + & + & 50.00 & + \\
\hline MT\#80 & $\mathrm{H}$ & O103:H2 & + & - & + & - & 3.12 & - \\
\hline TB154A & $\mathrm{H}$ & O103:H2 & + & - & + & - & 3.12 & - \\
\hline 8419 & $\mathrm{H}$ & O103:H25 & + & - & + & + & 50.00 & + \\
\hline $15612-1$ & $\mathrm{C}$ & O103:H11 & + & - & + & + & 282.84 & + \\
\hline CDC 90-3128 & $\mathrm{H}$ & O103:H2 & + & - & + & + & 282.84 & + \\
\hline 2006-3008 & $\mathrm{U}$ & O103:H11 & + & - & + & + & 200.00 & + \\
\hline $236-5$ & $\mathrm{C}$ & $\mathrm{O} 103$ & + & + & + & + & 200.00 & + \\
\hline $6: 38$ & $\mathrm{H}$ & $\mathrm{O} 103: \mathrm{H} 2$ & + & - & + & + & 200.00 & + \\
\hline RW1372 & $\mathrm{C}$ & O103:H2 & + & - & + & - & 6.25 & - \\
\hline $89-118$ & $\mathrm{C}$ & O103:NM & + & - & + & + & 282.84 & + \\
\hline RD8 & $\mathrm{H}$ & O111:H10 & - & + & - & + & 141.42 & + \\
\hline $3215-99$ & $\mathrm{H}$ & O111:H8 & + & + & + & + & 200.00 & + \\
\hline 02019611 & $\mathrm{H}$ & O111:H8 & + & - & + & + & 200.00 & + \\
\hline $7726-1$ & $\mathrm{C}$ & O111 & + & + & + & + & 200.00 & + \\
\hline $8266-1$ & $\mathrm{C}$ & O111 & + & + & + & + & 141.42 & + \\
\hline 10049 & $\mathrm{C}$ & O111:H11 & + & - & + & + & 400.00 & + \\
\hline JB1-95 & $\mathrm{H}$ & O111 & + & + & + & + & 200.00 & + \\
\hline АТСС ВАA-2440 & $\mathrm{OH}$ & O111:H8 & + & + & + & + & 282.84 & + \\
\hline DEC8b & $\mathrm{C}$ & O111:H8 & + & + & + & + & 282.84 & + \\
\hline IHIT1703 & $\mathrm{C}$ & O111:H2 & + & - & + & + & 200.00 & + \\
\hline DA-5 & $\mathrm{H}$ & O121:H19 & - & + & + & + & $35 \cdot 36$ & + \\
\hline MT\#2 & $\mathrm{H}$ & O121:H19 & - & + & + & + & 50.00 & + \\
\hline DA-37 & $\mathrm{H}$ & O121:H19 & - & + & + & + & 25.00 & + \\
\hline E191F-1 & $\mathrm{C}$ & O121:H19 & - & + & + & + & 70.71 & + \\
\hline KDHE 55 & $\mathrm{H}$ & $\mathrm{O} 121$ & - & + & + & + & 25.00 & + \\
\hline CDC 97-3068 & $\mathrm{H}$ & O121:H19 & - & + & + & + & 50.00 & + \\
\hline $2002-3211$ & $\mathrm{H}$ & O121:H19 & - & + & + & + & 50.00 & + \\
\hline $3377-85$ & $\mathrm{H}$ & O121:H19 & - & + & + & + & 70.71 & + \\
\hline
\end{tabular}


Table 1 (continued)

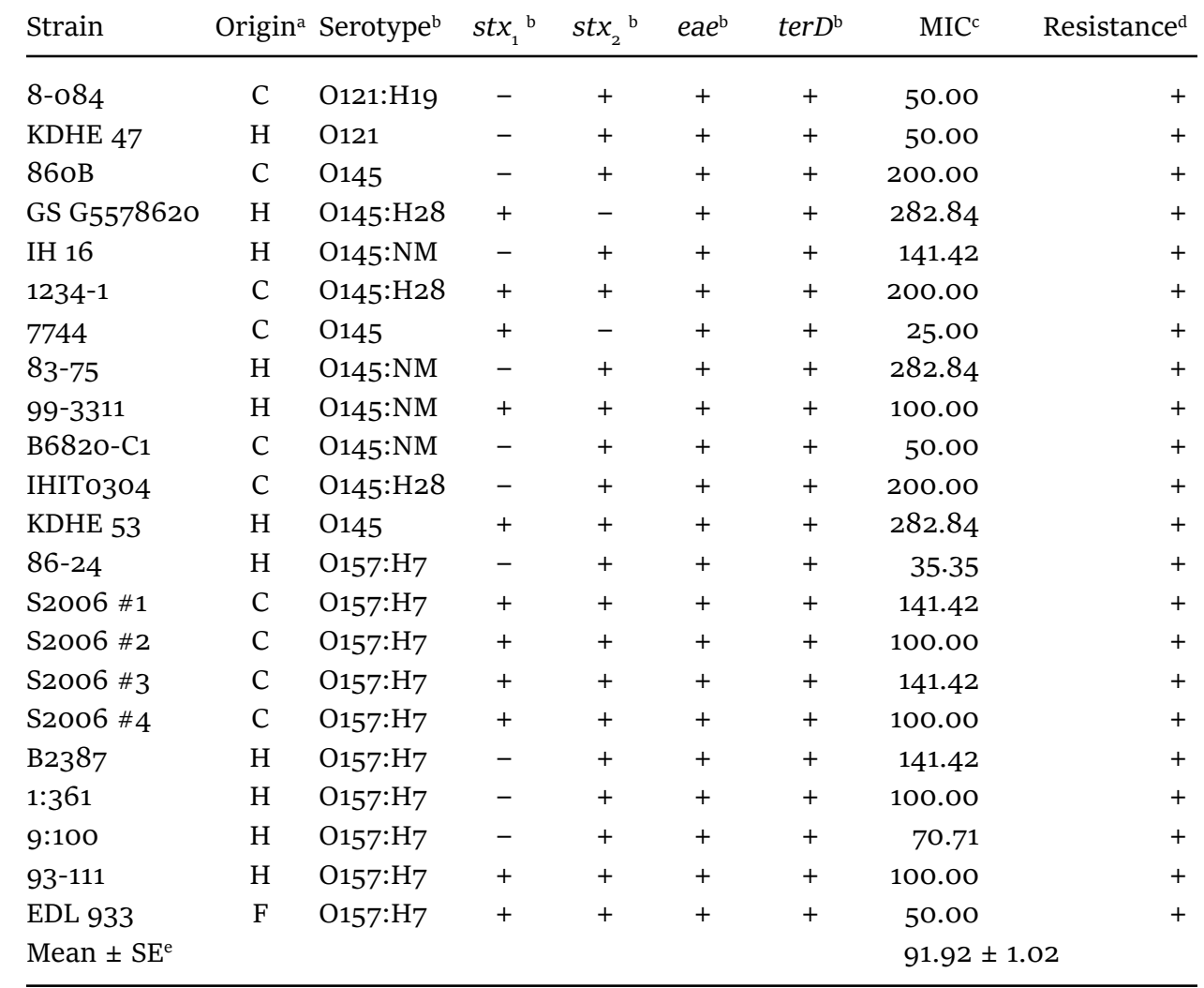

a. $H$ human (clinical), $C$ cattle (feces), $U$ unknown, $F$ food (hamburger)

b. Serotype based on molecular and/or genotypic (PCR) characterization; H-type was not determined for some strains and in this case, left blank, or listed as NM, non-motile if known; Shiga toxin gene (stx) subtype; 1, stx1; 2 , stx2. Presence $(+)$ or absence $(-)$ of intimin (eae) and tellurite-resistance $(\operatorname{ter} D)$ genes

c. Geometric mean calculated from log2- transformed $\mathrm{K}_{2} \mathrm{TeO}_{3} \mathrm{MIC}$ (mg/L); data from two experiments

d. Resistant (+) and susceptible ( - ) strains based on mean $\mathrm{K} 2 \mathrm{TeO} 3 \mathrm{MIC}$ of $\geq 25$ and $<25$ $\mathrm{mg} / \mathrm{L}$, respectively

e. Geometric mean \pm standard error $\mathrm{K}_{2} \mathrm{TeO}_{3} \mathrm{MIC}(\mathrm{mg} / \mathrm{L})$ of all STEC strains in study $(n=70)$

by suspending an individual isolated colony in $50 \mu \mathrm{L}$ of ultrapure water and heating at $95{ }^{\circ} \mathrm{C}$ for $10 \mathrm{~min}$. Individual PCR reactions were conducted using a Bio-Rad T100 ${ }^{\mathrm{TM}}$ Thermal Cycler (Bio-Rad, Hercules, CA). Primers targeting terD (Eurofins MWG Operon) and reaction conditions were as described by Taylor et al. [17]. Each $25-\mu \mathrm{L}$ PCR reaction contained $2.5 \mu \mathrm{L}$ of $10 x$ ThermoPol buffer, $0.5 \mu \mathrm{L}$ of dNTP mix, $0.5 \mu \mathrm{L}$ of Taq polymerase (New England BioLabs, Ipswich, MA), 2.0 $\mu \mathrm{L}$ of each primer (forward and reverse), and $2.0 \mu \mathrm{L}$ of the appropriate DNA template. PCR products were visualized by using either a QIAxcel 
Table 2 Minimum inhibitory concentrations (MIC) for $\mathrm{K}_{2} \mathrm{TeO}_{3}$ and polymerase chain reaction (PCR) assay results for terD in non-STEC control organisms

\begin{tabular}{|c|c|c|c|}
\hline Organism name (strain) & $\mathrm{MIC}^{\mathrm{a}}$ & Resistance $^{\mathrm{b}}$ & $\operatorname{ter} D$ \\
\hline Aeromonas hydrophila & 12.50 & - & + \\
\hline Citrobacter freundii & 0.78 & - & + \\
\hline Corynebacterium renale & 25.00 & + & - \\
\hline Enterobacter cloacae & 0.78 & - & + \\
\hline Enterococcus faecalis & $>400.00$ & + & + \\
\hline Escherichia coli (8863-88-1) & 6.25 & - & - \\
\hline Escherichia coli (ATCC 25922) & 0.20 & - & - \\
\hline Escherichia coli (11182-2) & 6.25 & - & + \\
\hline Escherichia coli (15195-2) & 6.25 & - & + \\
\hline Escherichia coli (16118-2) & 6.25 & - & + \\
\hline Escherichia coli (17298-2) & $4 \cdot 42$ & - & + \\
\hline Escherichia coli (2534-86) & 1.10 & - & + \\
\hline Escherichia coli (G58-1) & 6.25 & - & + \\
\hline Escherichia vulneris & 100.00 & + & + \\
\hline Klebsiella pneumoniae & 3.12 & - & + \\
\hline Kosakonia cowanii & 12.50 & - & - \\
\hline Listeria monocytogenes & 200.00 & + & + \\
\hline Micrococcus luteus & 100.00 & + & + \\
\hline Morganella morganii & 6.25 & - & + \\
\hline Pantoea sp. & 400.00 & + & - \\
\hline Pasteurella multocida & 200.00 & + & + \\
\hline Proteus mirabilis & $>400.00$ & + & + \\
\hline Proteus vulgaris & 400.00 & + & - \\
\hline Providencia rettgeri & 0.20 & - & - \\
\hline Pseudomonas aeruginosa & $35 \cdot 36$ & + & + \\
\hline Pseudomonas koreensis & 100.00 & + & - \\
\hline Rhodococcus equi & 400.00 & + & - \\
\hline Salmonella ser. Choleraesuis & 100.00 & + & + \\
\hline Salmonella ser. Gallinarum & $35 \cdot 36$ & - & + \\
\hline Salmonella ser. Pullorum & 6.25 & - & + \\
\hline Salmonella ser. Typhimurium & 1.56 & - & + \\
\hline Serratia marcescens & 0.20 & - & + \\
\hline Staphylococcus aureus & $>400.00$ & + & + \\
\hline Staphylococcus epidermidis & 100.00 & + & - \\
\hline Staphylococcus intermedius & 100.00 & + & + \\
\hline Streptococcus gallolyticus (VDC 10941-01-2) & 400.00 & + & + \\
\hline Streptococcus gallolyticus (VDC 21353-05-1) & $>400.00$ & + & + \\
\hline Streptococcus uberis & 100.00 & + & - \\
\hline Yersinia enterocolitica & 0.55 & - & + \\
\hline Yersinia ruckeri 25.00 & + & - & \\
\hline Mean $\pm \mathrm{SE}^{\mathrm{c}}$ & 19.82 & & \\
\hline
\end{tabular}

a. Geometric mean calculated from log2- transformed $\mathrm{K}_{2} \mathrm{TeO} 3 \mathrm{MIC}(\mathrm{mg} / \mathrm{L})$ based on data from two experiments

b. Resistant strains (+) have mean $\mathrm{K}_{2} \mathrm{TeO}_{3} \mathrm{MIC} \geq 25 \mathrm{mg} / \mathrm{L}$. Susceptible strains (-) have mean tellurite MIC $<25 \mathrm{mg} / \mathrm{L}$

c. Geometric mean \pm standard error $\mathrm{K}_{2} \mathrm{TeO}_{3} \mathrm{MIC}(\mathrm{mg} / \mathrm{L})$ of all control strains in study $(n=40)$ 
Table 3 Mean $\mathrm{K}_{2} \mathrm{TeO}_{3}$ minimum inhibitory concentrations (MIC) and tellurite-susceptible or -resistant status of terD- versus terD+ STEC strains and control Organisms

\begin{tabular}{|c|c|c|c|c|}
\hline & \multicolumn{2}{|l|}{ STEC } & \multicolumn{2}{|c|}{ Control organisms } \\
\hline & $\operatorname{ter} D-\mathrm{a}$ & $\operatorname{ter} D+^{\mathrm{a}}$ & $\operatorname{ter} D-$ & $\operatorname{ter} D+$ \\
\hline $\mathrm{MIC}$ mean $\pm \mathrm{SE}^{\mathrm{b}}$ & $4.05 \pm 1.09$ & $111.07 \pm 1.01 *$ & $26.54 \pm 1.17$ & $17.47 \pm 1.09$ \\
\hline Number of strains tested & 4 & 66 & 12 & 28 \\
\hline Number susceptible ${ }^{c}$ & 4 & $\mathrm{o}$ & 4 & 16 \\
\hline Number resistant ${ }^{\mathrm{d}}$ & $\mathrm{O}$ & 66 & 8 & 12 \\
\hline
\end{tabular}

a. ter $D$ negative (ter $D-$ ) or ter $D$ positive (ter $D+$ ) based on PCR results

b. Geometric mean \pm standard error mean calculated from log2- transformed MIC (mg/L) based on data from two experiments. Asterisk denotes significant difference $(P<0.05)$ between terD- and terD+ strains

c. Number of strains susceptible to $\mathrm{K}_{2} \mathrm{TeO}_{3}$, designated by $\mathrm{MIC}<25 \mathrm{mg} / \mathrm{L}$

d. Number of strains resistant to $\mathrm{K}_{2} \mathrm{TeO}_{3}$, designated by $\mathrm{MIC} \geq 25 \mathrm{mg} / \mathrm{L}$

automated capillary electrophoresis instrument and the QIAxcel DNA Screening Kit (Qiagen, Hilden, Germany) or on an ethidium bromide stained 2\% agarose gel. O157:H7 STEC strain EDL 933 was used as a positive control for the presence of ter $D$, and $2 \mu \mathrm{L}$ of ultrapure water was used in place of DNA template as the negative control. For each strain tested, two independent PCR experiments, consisting of two technical replicates each, were conducted.

\section{Minimum Inhibitory Concentration (MIC)}

Cation-adjusted Mueller-Hinton broth (CAMHB) was used as both diluent and liquid growth media in this experiment (Becton, Dickinson and Company, Franklin Lakes, NJ). Serial two-fold dilutions of solution were carried out resulting in 14 different tellurite concentrations ranging from 0.1 to $800 \mathrm{mg} / \mathrm{L}$; a solution of CAMHB with no $\mathrm{K}_{2} \mathrm{TeO}_{3}$ was used for control purposes. Ninety-six well microtiter plates containing replicates of $50 \mu \mathrm{L}$ of a concentration per well were used to conduct MICs. Plates prepared prior to inoculation were sealed and stored at $-20{ }^{\circ} \mathrm{C}$ until used.

Each strain was streaked for isolation on BAP and incubated overnight at $37^{\circ} \mathrm{C}$. Individual colonies were picked into $5 \mathrm{~mL}$ of Sensititre $\mathrm{TM}^{\mathrm{TM}}$ demineralized water (Thermo Scientific, Waltham, MA) to achieve a bacterial suspension equivalent to $0.5 \mathrm{McF}$ arland unit (approximately $10^{8} \mathrm{CFU} / \mathrm{mL}$ ) as determined by a Sensititre ${ }^{\mathrm{TM}}$ AutoInoculator (Thermo 
Scientific, Waltham, MA). $10 \mu \mathrm{L}$ of each bacterial suspension was added to $11 \mathrm{~mL}$ of Sensititre ${ }^{\text {TM }}$ CAMHB w/TES [ $N$-tris(hydroxymethyl) methyl-2-aminoethanesulfonic acid] (Thermo Scientific, Waltham, MA). $50 \mu \mathrm{L}$ of the final inoculated CAMHB was added to a well of the thawed 96-well plate with the exception of the negative control wells. The inoculation format resulted in two wells per strain per $\mathrm{K}_{2} \mathrm{TeO}_{3}$ concentration. Culture purity was confirmed using a subsample from the inoculated positive control wells. All plates were incubated at $37^{\circ} \mathrm{C}$ for $18 \mathrm{~h}$. A Sensititre ${ }^{\mathrm{TM}}$ Manual Viewbox (Thermo Scientific, Waltham, MA) was used to determine the presence or absence of growth. Visualized growth was scored as positive. For each strain tested, two technical replicates were performed for each of the two independent MIC experiments. The MIC of a strain was determined as the lowest tellurite concentration that inhibited growth in both technical replicates in an experiment [5]. The $\log _{2}$ - transformed MIC of each strain in each experiment and the geometric mean MIC of each strain using the $\log _{2}$ - transformed data from both experiments was determined. In the case of MICs $\geq 400 \mathrm{mg} / \mathrm{L}$, a value of $400 \mathrm{mg} / \mathrm{L}$ was used for the $\log _{2}$ transformation to allow for calculation of a geometric mean. The geometric mean and standard error for each STEC serogroup, all STEC combined, and all control strains combined were determined from the $\log _{2}$ - transformed data from individual strains. The minimum concentration required to inhibit growth of $90 \%$ of strains tested in each serogroup was determined as the $\mathrm{MIC}_{90}[5]$.

\section{Statistical Analysis}

All statistical analyses were performed using JMP Pro Version 10.0 (SAS Institute, Cary, NC). An analysis of means for proportions using an adjusted Wald test was used to analyze the proportions of STEC and control organisms that tested positive for ter $D(\operatorname{ter} D+$ ) by PCR. The Student's $t$ test was used to determine whether the geometric mean MIC for the following group comparisons were significantly different using $\alpha$ at 0.05: (1) STEC isolates versus control isolates; (2) terD+ STEC versus terD-negative (terD-) STEC; and (3) terD+ controls versus terD- controls. A one-way analysis of variance (ANOVA) followed by Tukey-Kramer HSD analysis was conducted on geometric means of $\mathrm{K}_{2} \mathrm{TeO}_{3} \mathrm{MIC}$ values for comparison at the serogroup level using $\alpha$ at 0.05 . 
Statistical analyses for agreement between terD PCR and $\mathrm{K}_{2} \mathrm{TeO}_{3}$ MIC results were performed by using Bowker's test to determine if there was significant symmetry of disagreement between the two tests. If Bowker's test was > 0.05, Cohen's kappa coefficient $(\kappa)$ was used to determine the level of agreement using the following criteria: if $\kappa \leq 0.20=$ poor; if $0.21 \leq \kappa \leq 0.40=$ fair; if $0.41 \leq \kappa \leq 0.6=$ moderate; $0.61 \leq \kappa \leq 0.80=$ good; and $0.81 \leq \kappa \leq 1.00=$ very good [1]. Isolates were classified as susceptible $(<25 \mu \mathrm{g} / \mathrm{mL})$ or resistant ( $\geq 25 \mu \mathrm{g} / \mathrm{mL}$ ) based on $\mathrm{K}_{2} \mathrm{TeO}_{3} \mathrm{MIC}$. Presence or absence of terD was based on PCR analysis. The relationship between the presence of intimin (eae) and $\mathrm{K}_{2} \mathrm{TeO}_{3}$ resistance was examined using Pearson's $\chi^{2}$ test.

\section{Results}

Sixty-six of 70 STEC strains (94.3\%) were positive for terD (Table 1) compared to 28 of 40 control organisms (70.0\%; Table 2; $P<$ o.001). The $\mathrm{K}_{2} \mathrm{TeO}_{3}$ geometric mean MIC for STEC strains was 91.92 $\pm 1.02 \mathrm{mg} / \mathrm{L}$ (Table 1 ), which was not significantly different from that of the control organisms (19.82 $\pm 3.86 \mathrm{mg} / \mathrm{L} ; P=0.375$; Table 2$)$. The $\mathrm{K}_{2} \mathrm{TeO}_{3}$ geometric mean MIC for terD+ STEC strains was significantly higher than that for ter $D-\operatorname{STEC}(P<0.0001$; Table 3$)$. In contrast, the $\mathrm{K}_{2} \mathrm{TeO}_{3}$ geometric mean MIC for terD+ control organisms was not significantly different from that of ter $D-$ control organisms $(P=0.6476$; Table 3). STEC isolates included in the analysis had insignificant symmetry of disagreement between the two testing methods by Bowker's test (0.3173); hence, they were subjected to Cohen's kappa coefficient $(\kappa)$ analysis. The $\kappa$ for agreement between presence or absence of ter $D$ and a resistant or susceptible phenotype, respectively, was o.881 (CI 0.626-1.11, SE 0.11) indicating a very good level of agreement (Table 3). Resistance to $\mathrm{K}_{2} \mathrm{TeO}_{3}$ ( $\mathrm{MIC} \geq 25 \mathrm{mg} / \mathrm{L}$ ) was exhibited by 65/66 ter $D+(98.5 \%)$ and o/4 terD- (o\%) STEC strains (Table 3). Control organisms had insignificant symmetry of disagreement, with a Bowker's test score of 0.144 . However, the $\kappa$ for agreement between presence or absence of terD and a resistant or susceptible phenotype, respectively, was - 0.173 (CI - 0.455 to 0.108 , SE 0.14 ) indicating no effective level of agreement. $\mathrm{K}_{2} \mathrm{TeO}_{3}$ resistance was exhibited by $12 / 28$ ter $D+$ control organisms $(42.9 \%)$ in comparison to $8 / 12$ terDstrains (66.7\%; Table 3). A significant relationship was demonstrated 
between presence of the gene for intimin (eae) and $\mathrm{K}_{2} \mathrm{TeO}_{3}$ resistance in STEC strains with a Pearson's $\chi^{2}$ test of $5.7(P=0.017)$.

The prevalence of terD among adulterant STEC serogroups was 7 of 10 in 0103 strains, whereas it was $\geq 9$ of 10 in all other serogroups. The $\mathrm{K}_{2} \mathrm{TeO}_{3}$ geometric mean MIC varied among STEC serogroups, with a rank order from highest to lowest of $\mathrm{O} 111>\mathrm{O} 26>\mathrm{O} 145$ $>0157>0103>0121=045$. Among individual strains, serogroups $\mathrm{O} 26$ and $\mathrm{O} 111$ consistently had $\mathrm{K}_{2} \mathrm{TeO}_{3} \mathrm{MIC} \geq 100 \mathrm{mg} / \mathrm{L}$, while $70 \%$ (7/10) and 80\% (8/10) of serogroup 0103 and 0121 strains, respectively, had $\mathrm{K}_{2} \mathrm{TeO}_{3} \mathrm{MIC}<100 \mathrm{mg} / \mathrm{L}$ (Table 1). Serogroup $\mathrm{O} 45$ and 0121 strains had the lowest mean $\mathrm{K}_{2} \mathrm{TeO}_{3} \mathrm{MIC}(43.52$ and $45.06 \mathrm{mg} / \mathrm{L}$, respectively) while O111 strains had the highest (214.36 mg/L). Significant differences using ANOVA followed by Tukey-Kramer HSD on geometric mean MIC values were present between the $\mathrm{O} 111$ and $\mathrm{O} 121$ serogroups $(P<0.0001), 0111$ and 045 serogroups $(P=0.0012)$, 026 and 0121 serogroups $(P=0.0044), 0145$ and 0121 serogroups $(P=$ 0.0080), O111 and $\mathrm{O} 157(P=0.0095)$, and $\mathrm{O} 26$ and $\mathrm{O} 45$ serogroups $(P=0.0437)$, respectively. The $\mathrm{MIC}_{90}$ of serogroups O26, O103, O111, and 0145 were $400 \mathrm{mg} / \mathrm{L}$, whereas that of $\mathrm{O} 45$ was $200 \mathrm{mg} / \mathrm{L}$ and O121 was $100 \mathrm{mg} / \mathrm{L}$.

\section{Discussion}

$\mathrm{K}_{2} \mathrm{TeO}_{3}$ has been used for over 100 years as a selective agent in media for the isolation of specific bacterial pathogens, e.g., Corynebacterium diphtheriae, Staphylococcus aureus, Vibrio cholerae, Shigella spp., and more recently, O157 STEC $[16,22]$. In addition, $\mathrm{K}_{2} \mathrm{TeO}_{3}$ has been used to select for non-O157 STEC, but great variations in STEC tellurite susceptibilities exist among these organisms [12]. This variability in $\mathrm{K}_{2} \mathrm{TeO}_{3}$ resistance, coupled with a lack of unique biochemical markers, has hampered development of highly effective selective media for non-O157 STEC [4, 12, 20], prompting the need for more research and the study conducted herein.

The results of this study were consistent with those of Orth et al. [13] in that all O26, O111, O145, and O157 STEC strains tested were ter $D+$ and there was a significant relationship between the presence of eae and $\mathrm{K}_{2} \mathrm{TeO}_{3}$ resistance. The results differed in that only seven of $10 \mathrm{O} 103$ STEC strains in the present study (70\%), in contrast to 
two of two $(100 \%)$ in the previous study [13], were terD+. The results of the present study extend the literature on $\mathrm{K}_{2} \mathrm{TeO}_{3}$ resistance and terD prevalence in USDA-FSIS-regulated STEC, and in particular $\mathrm{O} 45$ [3, 4, 6, 9, 10, 12, 13, 15, 17, 22]. The study by Orth et al. [13] included no $\mathrm{O} 45$ or $\mathrm{O} 121$ STEC strains. The study by Kerangart et al. [12] included only one 045 STEC strain, which was ter $D+$, but did include 8-10 strains of each of the other serogroups. In general, our results parallel those of Kerangart et al. [12]; however, one difference was our finding that the geometric mean $\mathrm{K}_{2} \mathrm{TeO}_{3} \mathrm{MIC}$ of $\mathrm{O}_{45}$ STEC was significantly lower than that of 026 and O111 STEC. Another was that the geometric mean $\mathrm{K}_{2} \mathrm{TeO}_{3} \mathrm{MIC}$ of $\mathrm{O}_{157}$ STEC ranked in the middle among USDAFSIS- regulated STEC serogroups, whereas based on our analysis of LB broth MIC data presented in the supplementary data file of the study by Kerangart et al. [12] it was the lowest. Two of 12 O157:H7 STEC strains they tested were terD-, whereas all 10 O157:H7 STEC strains in our study were terD+.

The $\mathrm{K}_{2} \mathrm{TeO}_{3} \mathrm{MIC}$ results of Orth et al. [13] were based on agar (LB and CT-SMAC), whereas Kerangart et al. [12] generated MIC data with both (LB) agar and (LB) broth, and they noted that agar yields values about one log lower than that of broth. However, Taylor et al. [17] determined the $\mathrm{K}_{2} \mathrm{TeO}_{3}$ MICs on a set of O157:H7 STEC strains on solid media and recorded values as high as $1024 \mu \mathrm{g} / \mathrm{mL}$. Fukushima et al. [6] conducted a similar test of $\mathrm{K}_{2} \mathrm{TeO}_{3} \mathrm{MIC}$ on solid media except they included non-O157 STEC as well. Although broth and agar MICs differ, our study confirmed the findings of Fukushima et al. [6] as $\mathrm{K}_{2} \mathrm{TeO}_{3}$ MIC varied by strain and serogroup, and expanded on it by including serogroup $\mathrm{O} 45$.

The fact that the Cohen's $\kappa$ coefficient indicated very good agreement between presence or absence of terD and a resistant or susceptible phenotype in STEC strains suggests that $\mathrm{K}_{2} \mathrm{TeO}_{3}$ resistance in these organisms is a function of the ter gene cluster, which supports the results of previous studies $[12,13,17]$. The lack of resistance to $\mathrm{K}_{2} \mathrm{TeO}_{3}$ in over half of the terD+ control organisms suggests these strains lacked a necessary component of the ter gene cluster or lacked another component needed for functional $\mathrm{K}_{2} \mathrm{TeO}_{3}$ resistance. In addition, the presence of resistance in two-thirds of the terD- control organisms suggests that another of the at least five known mechanisms of $\mathrm{K}_{2} \mathrm{TeO}_{3}$ resistance was involved [16]. 


\section{Conclusions}

The prevalence of terD was significantly higher in STEC than in non-STEC control strains. The level of agreement between terD PCR and $\mathrm{K}_{2} \mathrm{TeO}_{3}$ minimum inhibitory concentration (MIC) was very good in STEC strains as determined by a Cohen's $\kappa$ coefficient analysis, supporting and extending the results of previous studies suggesting that the genetic basis for $\mathrm{K}_{2} \mathrm{TeO}_{3}$ resistance in STEC is due to the ter gene cluster. In contrast, there was a significant disagreement between terD PCR and $\mathrm{K}_{2} \mathrm{TeO}_{3} \mathrm{MIC}$ in non-STEC control organisms. The presence of resistance in nearly half of the terD-control organisms suggests that another mechanism of $\mathrm{K}_{2} \mathrm{TeO}_{3}$ resistance was involved. The seven USDA-FSIS adulterant serogroups varied in prevalence of terD and levels of $\mathrm{K}_{2} \mathrm{TeO}_{3}$ resistance. Among STEC serogroups, the prevalence of terD was lowest in 0103 STEC strains (70\%), whereas the prevalence in all other serogroups was $\geq 90 \%$ (9 of 10). These results confirm previous studies showing the significantly higher prevalence of the ter gene cluster in STEC strains, and the relationship between presence of these genes and $\mathrm{K}_{2} \mathrm{TeO}_{3}$ resistance in STEC and especially intimin (eae)-positive STEC, in contrast to non-STEC organisms. These results expand on the literature by the finding that $\mathrm{O} 45$ and O121 STEC, although frequently terD positive, on average have significantly lower levels of $\mathrm{K}_{2} \mathrm{TeO}_{3}$ resistance than USDA-regulated serogroups O26, O111, and O145.

Acknowledgements - This work is supported by Agriculture and Food Research Initiative grant no. 2012-68003-30155 from the U.S. Department of Agriculture (USDA), National Institute of Food and Agriculture. The authors thank Jamie Bauman, Robert Fenton, Alexander Mueting, Matthew Schaich, Brandon Stewart, and Dr. Zachary Stromberg for laboratory assistance.

Conflict of interest - Dr. Loy has served as a consultant for, and thus has disclosed a significant financial interest in Harrisvaccines. In accordance with its Conflict of Interest policy, the University of Nebraska-Lincoln's Conflict of Interest in Research Committee has determined that this must be disclosed. 


\section{References}

1. Altman DG (ed) (1990) Practical statistics for medical research. Chapman and Hall, CRC Press, London

2. Bai J, Paddock ZD, Shi X, Li S, An B, Nagaraja TG (2012) Applicability of a multiplex PCR to detect the seven major Shiga toxin-producing Escherichia coli based on genes that code for serogroup-specific O-antigens and major virulence factors in cattle feces. Foodborne Pathog Dis 9:541-548

3. Bielaszewska M, Zhang W, Tarr PI, Sonntag A-K, Karch H (2005) Molecular profiling and phenotype analysis of Escherichia coli O26:H11 and O26:NM: secular and geographic consistency of enterohemorrhagic and enteropathogenic isolates. J Clin Microbiol 43:4225-4228

4. Catarame TM, O'Hanlon KA, Duffy G, Sheridan JJ, Blair IS, McDowell DA (2003) Optimization of enrichment and plating procedures for the recovery of Escherichia coli O111 and O26 from minced beef. J Appl Microbiol 95:949-957

5. Clinical and Laboratory Standards Institute. (2012) Methods for dilution antimicrobial susceptibility tests for bacteria that grow aerobically; approved standard - ninth edition. Supplement Mo7- A9. Clinical and Laboratory Standards Institute, Wayne, PA

6. Fukushima H, Hoshina K, Gomyoda M (2000) Selective isolation of eae-positive strains of Shiga toxin-producing Escherichia coli. J Clin Microbiol 38:1684-1687

7. Gould LH, Mody RK, Ong KL, Clogher P, Cronquist AB, Garman KN, Lathrop S, Medus C, Spina NL, Webb TH, White PL, Wymore K, Gierke RE, Mahon BE, Griffin PM, Emerging Infections Program FoodNet Working Group (2013) Increased recognition of non-O157 Shiga toxin-producing Escherichia coli infections in the United States during 2000-2010: epidemiological features and comparison with E. coli O157 infections. Foodborne Pathog Dis 10:453-46o

8. Gyles CL (2007) Shiga toxin-producing Escherichia coli: An overview. J Anim Sci 85:E45-E62

9. Hiramatsu R, Matsumoto M, Miwa Y, Suzuki Y, Saito M, Miyazaki Y (2002) Characterization of Shiga toxin-producing Escherichia coli O26 strains and establishment of selective isolation media for these strains. J Clin Microbiol 40:922-925

10. Hirvonen JJ, Siitonen A, Kaukoranta SS (2012) Usability and performance of CHROMagar STEC medium in detection of Shiga toxin-producing Escherichia coli strains. J Clin Microbiol 50:3586-3590

11. Jobling MG, Ritchie DA (1988) The nucleotide sequence of a plasmid determinant for resistance to tellurium anions. Gene 66:245-248

12. Kerangart S, Douëllou T, Delannoy S, Fach P, Beutin L, Sergentet- Thévenot D, Cournoyer B, Loukiadis E (2016) Variable tellurite resistance profiles of clinically-relevant Shiga toxin-producing Escherichia coli (STEC) influence their recovery from foodstuffs. Food Microbiol 59:32-42 
13. Orth D, Grif K, Dierich M, Wurzner R (2007) Variability in tellurite resistance and the ter gene cluster among Shiga toxin-producing Escherichia coli isolated from humans, animals and food. Res Microbiol 158:105-111

14. Painter JA, Hoekstra RM, Ayers T, Tauxe RV, Braden CR, Angulo FJ, Griffin PM (2013) Attribution of foodborne illnesses, hospitalizations, and deaths to food commodities by using outbreak data, United States, 1998-2008. Emerg Infect Dis 19:407-415

15. Tarr PI, Bilge SS, Vary JC Jr, Jelacic S, Habeeb RL, Ward TR, Baylor MR, Besser TE (2000) Iha: a novel Escherichia coli O157:H7 adherence-conferring molecule encoded on a recently acquired chromosomal island of conserved structure. Infect Immun 68:1400-1407

16. Taylor D (1999) Bacterial tellurite resistance. Trends Microbiol 7:111-115

17. Taylor D, Rooker M, Keelan M, Ng LK, Martin I, Perna NT, Burland NTV, Blattner FR (2002) Genomic variability of $\mathrm{O}$ islands encoding tellurite resistance in enterohemorrhagic Escherichia coli O157:H7 isolates. J Bacteriol 184:4690-4698

18. U.S. Centers for Disease Control and Prevention (2013) Tracking and reporting foodborne disease outbreaks. Available at: http://www.cdc.gov/features/ dsfoodborneoutbreaks/. Accessed 29 Jan 2016

19. U.S. Department of Agriculture, Food Safety and Inspection Service (2012) Risk profile for pathogenic non-O157 Shiga toxinproducing Escherichia coli (non-O157 STEC). Available at: http:// www.fsis.usda.gov/share d/PDF/Non O157 Risk Profi le My2012.pdf. Accessed 29 Jan 2016

20. Wang F, Yang Q, Kase JA, Meng J, Clotilde LM, Lin A, Ge B (2013) Current trends in detecting non-O157 Shiga toxin-producing Escherichia coli in food. Foodborne Pathog Dis 10:665-677

21. Whelan KF, Colleran E, Taylor DE (1995) Phage inhibition, colicin resistance, and tellurite resistance are encoded by a single cluster of genes on the IncHI2 plasmid R478. J Bacteriol 177:5016-5027

22. Zadik PM, Chapman PA, Siddons CA (1993) Use of tellurite for the selection of verocytotoxigenic Escherichia coli O157. J Med Microbiol 39:155-158 